\title{
Order of action of components in the yeast pheromone response pathway revealed with a dominant allele of the STE11 kinase and the multiple phosphorylation of the STE7 kinase
}

\author{
Bradley R. Cairns, ${ }^{1,3}$ Sandra W. Ramer, ${ }^{2}$ and Roger D. Kornberg ${ }^{1}$ \\ ${ }^{1}$ Department of Cell Biology and ${ }^{2}$ Department of Biochemistry, Stanford University School of Medicine, Stanford, California \\ 94305 USA
}

The signal transduction pathway that mediates the response of haploid yeast cells to peptide mating pheromones involves several components including the protein kinases STE7 and STE11. We have isolated and characterized a dominant allele of the STE11 gene and have demonstrated that expression of an amino-terminally truncated form of STE11 protein causes constitutive activation of the mating pathway. Expression of this dominant STE11 allele also restored mating ability to certain sterile strains. In conjunction with the results of others, our epistasis results establish the following order of action of pathway components: STE2, GPA1(SCG1), STE4, STE5, STE11, STE7, STE12. Transduction of the signal from STE11 to STE7 may involve phosphorylation because STE7 displays several phosphorylation forms, and STE7 is multiply phosphorylated in response to either pheromone or coexpression of dominant STE11 protein. Further signal propagation appears to require STE7 protein kinase activity, because a catalytically impaired STE7 mutant is defective in the mating response.

[Key Words: Yeast; STE7 kinase; STE11 kinase; signal transduction; dominant allele; protein kinase]

Received March 11, 1992; revised version accepted May 26, 1992.

Signal transduction from the cell surface to targets inside the nucleus plays an important role in many cellular and developmental processes. Current studies of signaling pathways focus on defining the components involved and elucidating the mechanisms underlying signal propagation. Of particular interest are the diverse pathways mediated by heterotrimeric $G$ proteins (for review, see Stryer and Bourne 1986; Gilman 1987). Several of these systems in higher eukaryotes appear to employ protein phosphorylation to transduce the signal downstream of the $G$ protein, but defining the kinases involved and identifying their substrates has proved difficult. The mating pheromone signal transduction pathway present in the budding yeast Saccharomyces cerevisiae is a genetically tractable model system for studying the role of phosphorylation in signaling systems mediated by $G$ proteins. Mating between haploid a and $\alpha$ yeast cells is achieved by the exchange of peptide mating pheromones, with conjugation resulting in the formation of diploid a/ $\alpha$ cells (Duntze et al. 1970; Hartwell 1973; Kurjan 1985; Bender and Sprague 1986). The response of haploid a cells to the mating pheromone $\alpha$-factor involves the

${ }^{3}$ Corresponding author. interaction of a specific transmembrane pheromone receptor with a signal transduction pathway that coordinates all cellular events necessary for conjugation: arrest of the cell cycle in $G_{1}$ phase, the rapid transcriptional induction of several genes required for mating, and the attendant physiological changes necessary for cell and nuclear fusion (for review, see Cross et al. 1988; Herskowitz 1989). An analogous pathway is present in haploid $\alpha$ cells (Bender and Sprague 1986; Nakayama et al. 1987). Genetic experiments have identified several components in the pheromone response pathway in a haploid cells, including the products of the STE2, STE4, STE5, STE7, STE11, STE12, and STE18 genes. Deletions or conditional mutations in any of these genes cause sterility (MacKay and Manney 1974a,b; Hartwell 1980). The STE2 gene encodes the transmembrane receptor for $\alpha$-factor and displays a transmembrane topology similar to the rhodopsin/ $\beta$-adrenergic family of receptors (Jenness 1983; Nakayama et al. 1985; Dixon et al. 1986). The nucleotide sequences of the yeast genes GPA1(SCG1), STE4, and STE18 implicate them as the respective $\alpha, \beta$, and $\gamma$ subunits of the $G$ protein coupled to the STE2 receptor in the yeast mating pathway (Dietzel and Kurjan 1987; Miyajima et al. 1987; Whiteway et al. 1989). 
The $\beta \gamma$-complex STE4/STE18, and not the $\alpha$-subunit GPA1(SCG1), is believed to be responsible for transducing the signal in the mating pathway (Blinder et al. 1989; Cole et al. 1990; Nomoto et al. 1990; Whiteway et al. $1990 \mid$. In mammalian cells, signal propagation by $\beta \gamma$ subunits has been demonstrated in the activation of $\mathrm{K}^{+}$ channels by phospholipase $\mathrm{A}_{2}$ (Kim et al. 1989) and in the stimulation of adenylyl cyclase II (Federman et al. 1992).

Although the pheromone receptor and the heterotrimeric $G$ protein subunits have been studied intensively, propagation of the signal downstream of these components is poorly understood. Only the putative target of the mating pathway, the DNA-binding transcriptional activator STE12, has been characterized in detail (Dolan et al. 1989; Errede and Ammerer 1989| In response to pheromone, STE12 has been shown to be phosphorylated rapidly (Song et al. 1991). In addition to the uncharacterized STE5 gene product, the pathway is believed to include four putative protein kinases; STE7, STE11, FUS3, and KSS1 (Chaleff and Tatchell 1985; Courchesne et al. 1989; Elion et al. 1990). Although both the STE7 and STE11 gene products are absolutely required for mating, deletion of either the FUS3 gene or the KSS1 gene has only a mild effect on mating efficiency (Courchesne et al. 1989; Elion et al. 1991). The combination of deletions of FUS3 and KSS1, however, confers sterility (Elion et al. 1991). The nucleotide sequences of the STE7 and STE11 genes show significant homology to serine/threonine protein kinases (Teague et al. 1986; Hanks et al. 1988; Rhodes et al. 1990). Although STE11 protein kinase activity is essential for the mating response, and a potential novel substrate of STE 11 has been reported, direct involvement of STE11 in propagation of the signal has not been demonstrated; neither the phosphorylation nor the catalytic activity of STE 11 protein is affected by the presence of pheromone (Rhodes et al. 1990).

Our characterization of a dominant STE11 allele provides further evidence that STE11 protein is directly involved in signal propagation. Our results suggest the presence of a catalytic and a regulatory domain in STE11 protein, and our analysis of double mutants establishes the functional order of several of the STE gene products in the mating pathway. In addition, we demonstrate that the phosphorylation of STE7 protein is correlated with mating pathway activation and that STE7 kinase activity is important for an efficient mating response.

\section{Results}

\section{Isolation of a dominant allele of STE11}

An inducible yeast expression library was prepared by fusing sheared, size-selected yeast genomic DNA to the GAL1 promoter in pYES-R (Elledge et al. 1991). Although fusion of DNA fragments to the GAL1 promoter allows their transcription to be regulated by carbon sources (Johnston and Davis 1984), this version of the GAL1 promoter does not provide an initiator for their translation. Rather, an initiation codon must be present in the cloned DNA, with the initiation of translation occurring predominantly at the initiator closest to the $5^{\prime}$ end of the resulting mRNA. In addition to yielding fulllength clones, this library may contain truncation mutants. A clone derived from a shearing event within the coding region of a gene can only be expressed if initiation of translation occurs at an internal AUG codon, leading to the synthesis of an amino-terminally truncated protein.

The library was screened for clones that cause galactose-dependent transcriptional activation of FUS1, a gene whose mRNA level increases 40-fold after the addition of mating pheromone (McCaffrey et al. 1987). The yeast strain NNY19, containing a chromosomally integrated copy of a FUS1-lacZ construct (Nomoto et al. 1990|, was transformed with library DNA, and transformants were selected on uracil-deficient media containing glucose. This selection permitted growth of the transformants, but the presence of glucose repressed transcription of the cloned DNA. Colonies transferred to nitrocellulose filters were incubated on uracil-deficient media containing galactose to induce transcription from the GAL1 promoter. Clones whose expression caused activation of the mating pathway were revealed by $\beta$-galactosidase expression (Schena et al. 1989). A plasmid containing an allele of the STE11 gene under control of the GAL1 promoter was isolated and identified by Southern blot analysis with a STE11 probe (data not shown). Details of the preparation and characterization of the genomic DNA expression library, including a complete description of the genetic screen and other activators of the mating response pathway, will be presented elsewhere (S. Ramer and R. Davis, in prep.).

\section{Characterization of a STE11 amino-terminal truncation mutant}

We sequenced this STE11 allele and discovered that a large part of the STE11-coding region was absent; only the carboxy-terminal coding region of the STE11 gene remained fused to the GAL1 promoter (pYGU-11 $\triangle \mathrm{N}$; Fig. 1A). Sequencing revealed that the first nucleotide of STE11 present in pYGU-11 $\Delta \mathrm{N}$ is an adenosine at position 1051 (with numbering according to Rhodes et al. 1990), whereas the initiator for the wild-type STE11 gene is located at nucleotide position 116-118, and the stop codon is located at position 2267-2269. This deletion resulted in the synthesis of a mutant form STE11 protein $(\mathrm{STE} 11 \Delta \mathrm{N})$, which lacks its amino terminus. Protein sequence comparison shows that STE $11 \Delta \mathrm{N}$ protein contains all of the conserved catalytic kinase subdomains (Hanks et al. 1988; Rhodes et al. 1990). Use of the GAL1 promoter confers catabolite regulation of transcription to the STE11 $\triangle N$ allele (Johnston and Davis 1984). In the absence of repressing carbon sources such as glucose or sucrose, the addition of galactose induces the transcription of STE11 $\triangle N$ at least 20 -fold (data not shown).

Three lines of reasoning indicate that translational initiation of STE $11 \Delta \mathrm{N}$ begins at the first in-frame AUG codon, located at nucleotide position 1139-1141: (1) The first AUG codon corresponds to the translation initia- 


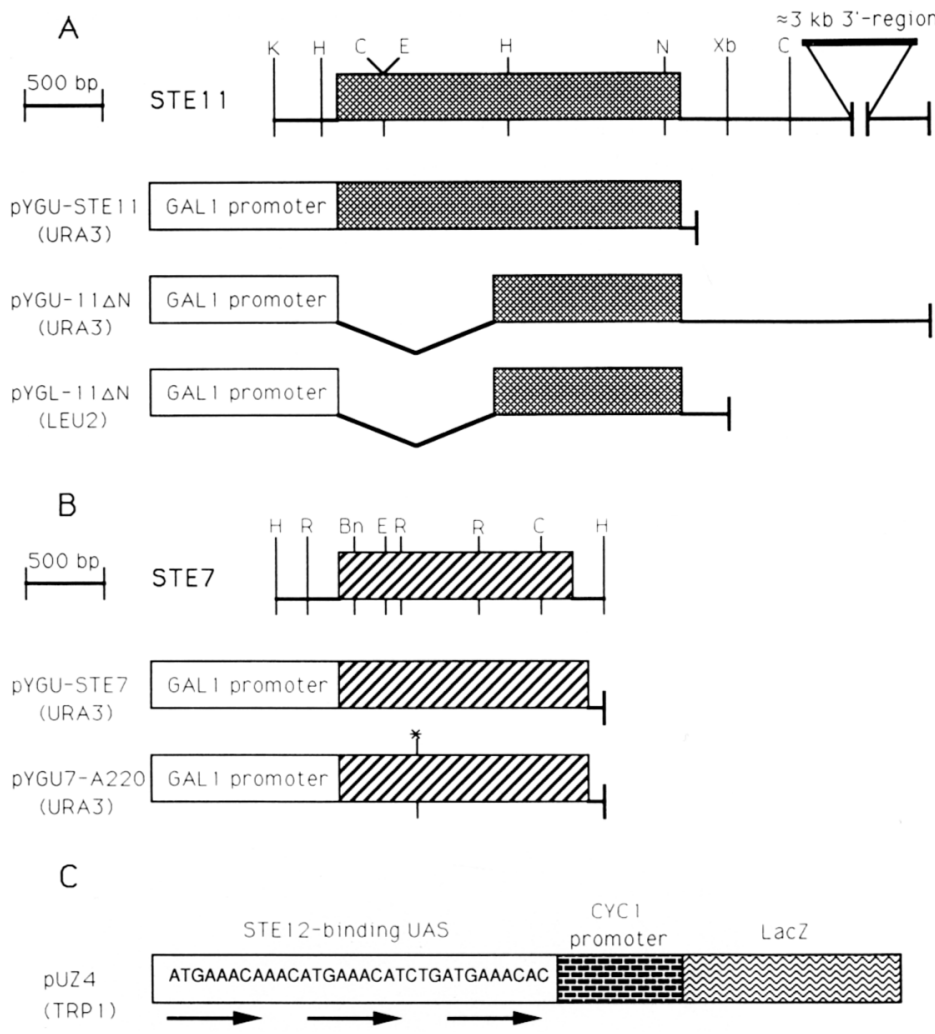

Figure 1. Plasmids employed in the expression and analysis of STE11 and STE7 protein. (A) Schematic representation of the plasmids directing STEll expression. The shaded area represents the coding region of STE11. pYGUSTE11 contains the wild-type STE11 gene under control of the GAL1 promoter. pYGU-STE11 $1 \mathrm{~N}$ contains $\sim 4 \mathrm{~kb}$ of uncharacterized DNA $3^{\prime}$ to the STE11-coding region, which is removed in pYGL-STE1 $1 \Delta \mathrm{N}$ without any loss of function. (B) Schematic representation of the plasmids directing STE7 expression. pYGU-STE7 contains the wild-type STE7 gene under control of the GAL1 promoter. pYGU7-A220 encodes a mutant form of $S T E 7$ protein in which the lysine at amino acid position 220 has been replaced with an arginine. (C) Schematic representation of the $\beta$-galactosidase reporter plasmid used to monitor STE12-dependent activation of transcription (pUZ4). The upstream activating sequence (UAS) contains three consensus-binding sites (ATGAAACA) for the DNA-binding protein STE12 (Kronstad et al. 1987; Van Arsdell and Thorner 1987; Dolan et al. 1989). These binding sites are tandemly repeated and are represented by arrows. Abbreviations of restriction sites: (Bn) BanII; (C) ClaI; (H) HindIII; (K) KpnHI; (N) NcoI; (R) EcoRI; (Xb) XbaI. tion site in $95 \%$ of yeast mRNA /Cigan and Donahue 1987 ); (2) initiation at the next in-frame AUG codon (nucleotides 1412-1414) would result in deletion of the entire first catalytic subdomain of the kinase; and (3) the presence of two additional out-of-frame AUG codons (nucleotides 1233-1235 and 1236-1238, respectively) between the first two in-frame AUG codons precludes the use of the initiator at positions 1412-1414. In addition, immunoblot analysis of STE $11 \Delta \mathrm{N}$ protein (with a polyclonal antibody raised against recombinant STE $11 \Delta \mathrm{N}$ protein) revealed a protein with an approximate mass of $48 \mathrm{kD}$ (Fig. 2A). On the basis of SDS-PAGE of native STE11 protein, which comprises 717 amino acids and migrates at $\sim 93 \mathrm{kD}$, translational initiation at position 1139 should result in a protein of 366 amino acids that migrates at $\sim 47 \mathrm{kD}$, in agreement with our findings.

\section{STE $11 \Delta \mathrm{N}$ is a dominant STE11 allele that causes pheromone-independent activation of the mating pathway}

STE1 $1 \Delta \mathrm{N}$ protein function was initially assessed by complementation of the mating defect conferred by a deletion of the STE11 gene (with YSC-A $\Delta$ ste11). Patches of YSC-A $\Delta$ stel 1 that express STE $11 \Delta \mathrm{N}$ protein were able to mate efficiently with tester lawns. No diploids were formed with control patches of YSC-A $\Delta$ ste11 not expressing STE1 $1 \Delta \mathrm{N}$ protein (data not shown). The effect of the STE11 $\triangle N$ allele on STE12-dependent transcription was examined in three wild-type strains (KMY211-A, YPH499, and W303-1A). All genes activated by the mat- ing pathway (in MATa cells) contain two or more binding sites for the STE12 protein. Transcriptional activation was monitored with the $\beta$-galactosidase reporter plasmid pUZ4 (Fig. 1C), which contains three consensus STE12binding sites (Kronstad et al. 1987; Van Arsdell and Thorner 1987; Dolan et al. 1989) upstream of the $\beta$-galactosidase gene. In all three strains, STE $11 \Delta \mathrm{N}$ expression activated STE12-dependent transcription to levels equal to or greater than levels observed by the addition of pheromone. Furthermore, high levels of STE12-dependent transcriptional activation (179 units) were observed when both STE1 $1 \Delta \mathrm{N}$ protein (with pYGL-11 $1 \Delta$; Fig. 1A) and STE11 wild-type protein /with pYGU-STE11; Fig. 1A) were overexpressed, indicating that the STE11 $\triangle N$ allele is dominant.

\section{Expression of STE11 $\mathrm{N}$ induces phenotypes similar to those observed following treatment with mating pheromone}

Activation of the mating pathway by mating pheromone causes the arrest of the cell cycle in $G_{1}$ phase, and several phenotypes including the accumulation of large unbudded cells and the formation of pear-shaped cells (shmoos) (Bucking-Throm et al. 1973; Wilkinson and Pringle 1974; Lipke et al. 1976). After $18 \mathrm{hr}$ of STE1 $1 \Delta \mathrm{N}$ expression, $>70 \%$ of cells accumulated as large unbudded cells, and $\sim 15 \%$ of these cells displayed projections typically observed upon treatment with a high concentration of mating pheromone (Fig. 3). These phenotypes were not a result of growth in galactose, nor did they occur when 
Cairns et al.

A

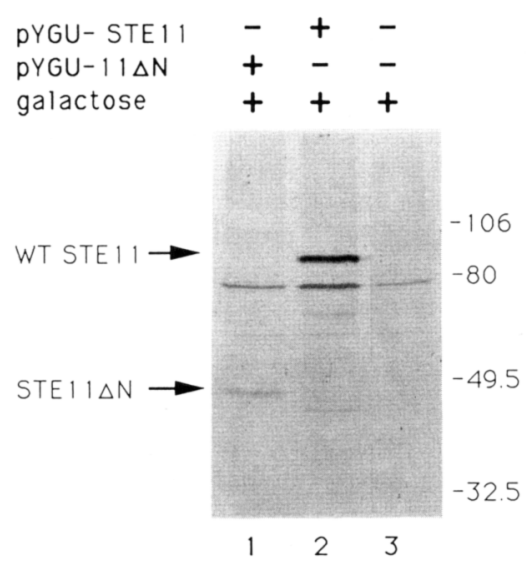

B

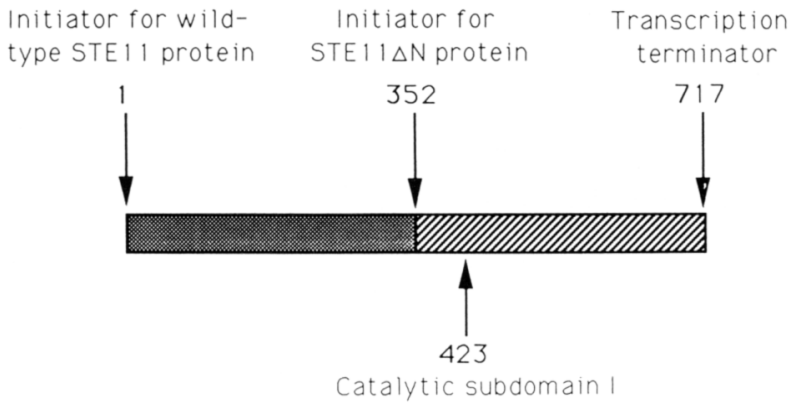

Figure 2. Immunoblot analysis of wild-type STE11 and STE $11 \Delta \mathrm{N}$ protein. $(A)$ Whole-cell extracts and immunoblots were prepared as described in Materials and methods. All lanes contain $\sim 5 \mu \mathrm{g}$ of whole-cell extract derived from YPH499 transformants. Each was grown for $8 \mathrm{hr}$ in the presence of galactose to induce expression from the following plasmids. (Lane 1) pYGU-11 $1 \Delta$; (lane 2) pYGU-STE11; (lane 3) no plasmid. The positions of wild-type STE1l protein and STE $1 \triangle \mathrm{N}$ protein are indicated by labeled arrows. Positions of molecular mass markers $(\mathrm{kD})$ run in another lane of the same gel are indicated at right. $(B)$ Schematic representation of the STE11-coding region, including the amino acid coordinates of the initiators of wildtype and truncated STEll protein, the first amino acid of the first conserved catalytic subdomain, and the last amino acid.

wild-type STE 11 was expressed for $18 \mathrm{hr}$ in YPH499 with pYGU-STE11 (data not shown). Further experiments are required to determine whether STE1 $1 \Delta \mathrm{N}$ expression affects the phenotype and the progression of the cell cycle by the same mechanisms as does pheromone treatment.

\section{Ordering the components of the mating pathway with STE11 $\triangle N$}

The epistatic relationships of the STE11 $\triangle N$ allele with other pathway components were assessed by determining the effect of STE11 $\Delta \mathrm{N}$ expression in strains lacking individual components of the mating pathway. In all cases, their ability to mate with an $\alpha$-tester strain and their ability to activate STE12-dependent transcription were determined (Table 1). STE11 $\Delta \mathrm{N}$ protein was ex- pressed in strains isogenic to KMY211-A, each lacking the STE4, STE5, STE7, STE11, or STE12 gene. In addition, the relationship of the STE1 $1 \Delta \mathrm{N}$ effect to the FUS3 and KSS1 kinases was tested by the expression of STE $11 \Delta \mathrm{N}$ in strains isogenic to YPH499 lacking either the FUS3 or KSS1 gene. Strains that lack either FUS3 alone or KSS1 alone are able to mate efficiently; only the double mutant $\Delta$ fus $3 \Delta k s s 1$ is sterile (Elion et al. 1991). Therefore, STE $1 \triangle \mathrm{N}$ protein was also expressed in a YPH499 derivative lacking both the FUS3 and KSS1 genes.

Expression of STE $11 \triangle \mathrm{N}$ protein in a strain lacking either the STE4 or STE5 gene restored a significant level of mating ability. In both of these strains, expression of STE11 N protein also resulted in high levels of STE12dependent transcription. In contrast, expression of STE $11 \triangle \mathrm{N}$ protein in a strain lacking either the STE7 or STE12 gene did not restore mating ability, nor did it
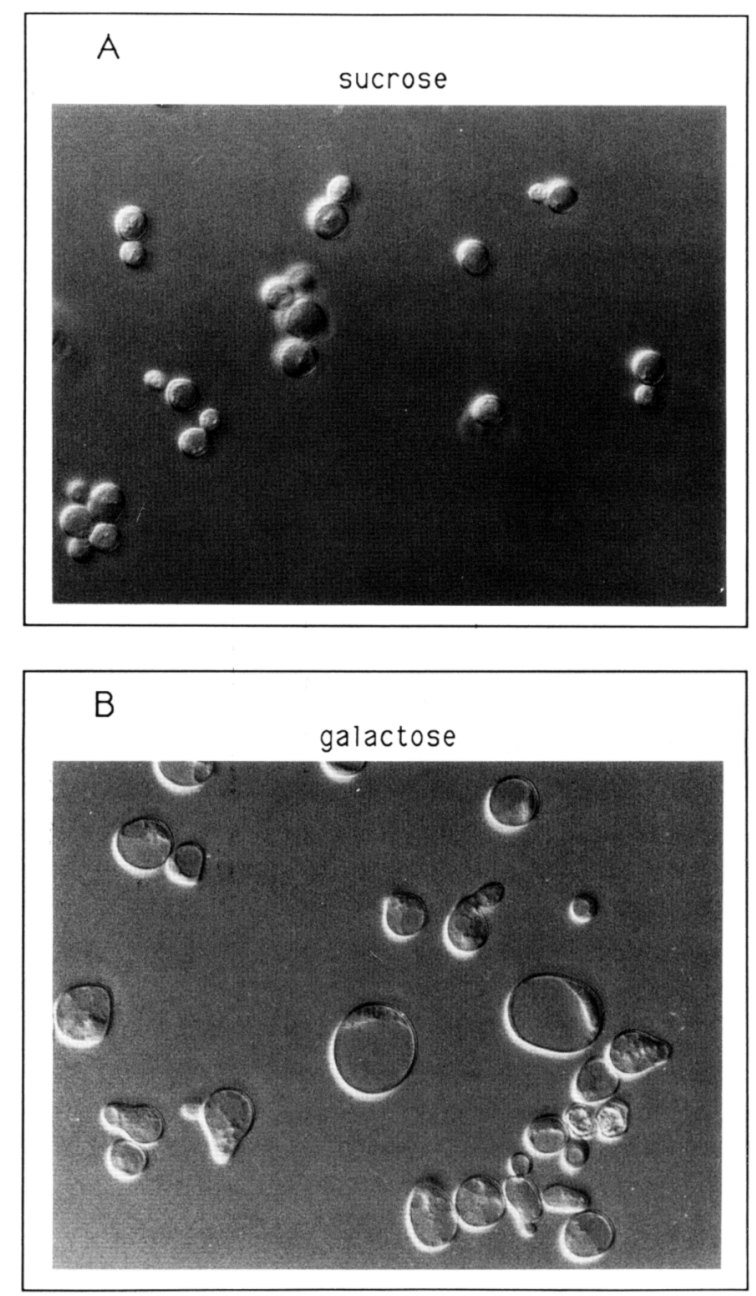

Figure 3. Phenotypes of yeast cells expressing STE $11 \Delta \mathrm{N}$ protein. $(A)$ The wild-type strain YPH499 was transformed with pYGU-11 $\Delta \mathrm{N}$ and grown to mid-log phase in medium containing $2 \%$ sucrose to prevent expression of STE $11 \Delta \mathrm{N}$. $(B)$ The transformants described in $A$ were centrifuged and resuspended in medium containing $2 \%$ galactose and grown for an additional $18 \mathrm{hr}$. Images were obtained with Normarski optics. 
Table 1. Effect of the dominant STE11 allele on mating and STE12-dependent transcription

\begin{tabular}{|c|c|c|c|c|c|}
\hline \multirow[b]{2}{*}{ Strain } & \multirow[b]{2}{*}{ Deletion } & \multirow{2}{*}{$\begin{array}{l}\text { Expression } \\
\text { Plasmid pYGU- }\end{array}$} & \multirow[b]{2}{*}{ Mating ${ }^{a}$} & \multicolumn{2}{|c|}{$\beta$-Galactosidase ${ }^{b}$} \\
\hline & & & & sucrose & galactose \\
\hline KMY211-A & none (wild type) & STE11 & +++ & $<1$ & $<1$ \\
\hline KMY211-A & none (wild type) & $11 \Delta \mathrm{N}$ & +++ & 2 & 281 \\
\hline YSC-A $\Delta$ ste $4^{c}$ & Aste4 & $11 \Delta \mathrm{N}$ & + & 2 & 267 \\
\hline YSC-A $\Delta$ ste $5^{c}$ & Aste5 & $11 \Delta \mathrm{N}$ & ++ & $<1$ & 208 \\
\hline YSC-A $\Delta$ ste $^{\mathrm{c}}$ & Aste7 & $11 \Delta \mathrm{N}$ & - & $<1$ & $<1$ \\
\hline YSC-A $\Delta$ ste $11^{c}$ & $\Delta s t e 11$ & $11 \Delta \mathrm{N}$ & +++ & $<1$ & 169 \\
\hline YSC-A $\Delta$ ste $12^{c}$ & $\Delta$ ste12 & $11 \Delta \mathrm{N}$ & - & $<1$ & $<1$ \\
\hline YPH499 & none (wild type) & STE11 & +++ & 2 & 2 \\
\hline YPH499 & none (wild type) & $11 \Delta \mathrm{N}$ & +++ & 2 & 444 \\
\hline YPHA $\Delta$ fus $3^{d}$ & $\Delta$ fus3 & $11 \Delta \mathrm{N}$ & +++ & $<1$ & 325 \\
\hline YPHA $\Delta \mathrm{kss} 1^{\mathrm{d}}$ & $\Delta k s s 1$ & $11 \Delta \mathrm{N}$ & +++ & $<1$ & 464 \\
\hline YPHA $\Delta$ fus $3 \Delta \mathrm{kss}^{\mathrm{d}}$ & $\Delta f u s 3, \Delta k s s 1$ & $11 \Delta \mathrm{N}$ & - & $<1$ & $<1$ \\
\hline
\end{tabular}

${ }^{a}$ Mating tests were performed by the patch method as described in Materials and methods. $(+\mid$ Patches comprising $10-30$ individual colonies form within $48 \mathrm{hr} .(++\mid$ Patches of diploids form within $48 \mathrm{hr}$ of replica plating. $|+++|$ Indistinguishable from wild-type. Dense patches of diploids form within $36 \mathrm{hr}$ of replica plating. (-) No diploids form within $96 \mathrm{hr}$ of replica plating.

${ }^{\mathrm{b}} \beta$-Galactosidase assays, with the reporter plasmid pUZ4 (Fig. 1C), are in Miller units as described in Materials and methods.

${ }^{\mathrm{K}} \mathrm{KMY} 211-\mathrm{A}$ strain background.

'YPH499 strain background.

cause any enhancement of STE12-dependent transcription. In addition, overproduction of wild-type STE11 protein with pYGU-STE11 did not restore mating ability to any of the deletion strains tested except YSC-A $\Delta$ stell. Assuming a linear relationship of mating pathway components, these results suggest that the STE $11 \Delta \mathrm{N}$ protein functions downstream of the STE4 and the STE5 gene products and upstream of the STE7 and STE12 gene products.

Expression of STE $11 \Delta \mathrm{N}$ protein in strains lacking either the FUS3 or KSS1 genes also caused high levels of STE12-dependent transcription. In contrast, expression of STEll$\Delta \mathrm{N}$ protein in the $\Delta f u s 3 \Delta k s s 1$ strain neither activated STE12-dependent transcription nor restored mating ability. These results localize the function of the FUS3 and KSS1 gene products downstream of the STE11 gene product and provide further evidence that the FUS3 and KSS1 kinases play redundant roles in activating gene expresssion (Elion et al. 1991).

\section{The STE7 kinase is a phosphoprotein}

As our data are consistent with the STE11 gene product functioning upstream of the STE7 gene product, we sought to identify the effects of the dominant STE11 mutation on the biochemical properties of the STE7 kinase. Polyclonal antisera were raised against recombinant STE7 protein and verified by immunoblot analysis of both the native recombinant protein (Fig. 4, lane 4) and a recombinant $\lambda c$ II fusion protein (data not shown).

As a result of the scarcity of STE7 protein in wild-type cells, we enhanced the levels of STE7 protein by directing STE7 synthesis from the galactose-inducible GAL1 promoter (Johnston and Davis 1984) with the plasmid pYGU-STE7 (Fig. 1B). Patches of the yeast strain YSCA $\triangle$ ste7, which lacks the STE7 gene, expressing STE7 protein with pYGU-STE7, mated efficiently with the $\alpha$-mating tester strain DC17 (data not shown), demonstrating functional complementation of the mating defect under these conditions. For immunoblot analysis, whole-cell extracts were prepared from a KMY211-A derivative lacking the STE7 gene (YSC-A $\Delta$ ste7), the wildtype strain KMY211-A, and a KMY211-A transformant that expressed STE7 protein with pYGU-STE7 (Fig. 4, lanes 1-3). Under these conditions, immunoblots did not reveal any STE7-dependent protein in extracts derived from wild-type cells (cf. lanes 1 and 2). When STE7 protein was expressed with pYGU-STE7, however, several galactose-dependent species appeared (lane 3), migrating with apparent masses between 64 and $76 \mathrm{kD}$. The most immunoreactive species was the fastest migrating and

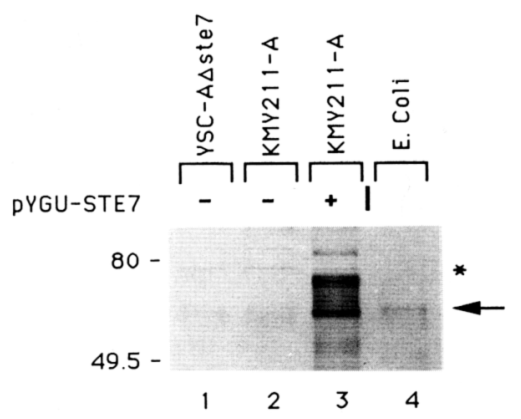

Figure 4. Immunoblot analysis of STE7 protein. Whole-cell extracts and immunoblots were prepared as described in Materials and methods from the following strains. (Lane 1) YSC-A $\Delta$ ste7, a KMY211-A derivative lacking the STE7 gene; (lane 2) KMY211-A (wild-type); (lane 3) KMY211-A transformed with pYGU-STE7 expressing STE7 from the GAL1 promoter (lanes $1-3$ contain $5 \mu \mathrm{g}$ of extract per lane); (lane 4$) \sim 2.0 \mathrm{ng}$ of recombinant STE7 protein purified from $E$. coli. The arrow indicates the position of unphosphorylated STE7 protein; the asterisk $(\star)$ indicates the position of the multiply phosphorylated form of the STE7 protein. Positions of molecular mass markers $(\mathrm{kD})$ run in another lane of the same gel are indicated at left. 
was shown to comigrate with STE7 protein produced in Escherichia coli (lane 4). In addition, a doublet representing the slowest-migrating species also exhibited a high level of immunoreactivity.

To determine whether these immunoreactive species represented different phosphorylation forms of STE7 protein, the lysates were treated with calf intestinal phosphatase (Fig. 5). This treatment converted all slow-migrating forms to an apparent single species migrating at $\sim 64 \mathrm{kD}$ (lane 2). This conversion did not occur in mocktreated lysates (lane 3 ) and was blocked by phosphatase inhibitors, indicating that the conversion was caused by dephosphorylation and not by proteolysis of STE7 protein.

Dephosphorylation experiments were also performed on immune complexes of STE7 protein. Under these conditions, dephosphorylation did not proceed to completion, presumably owing to protection of areas of STE7 protein by the polyclonal antibody. Immunoblot analysis of STE7 protein under these conditions reveals the accumulation of STE7 phosphorylation forms of intermediate electrophoretic mobility (Fig. 5, lane 5). This result indicates that the slow-migrating STE7 phosphorylation forms arise from multiple phosphorylations and argues against the possibility that each form represents a unique singly phosphorylated species.

\section{STE7 is phosphorylated rapidly in the presence of mating pheromone}

Having demonstrated the occurrence of STE7 phospho-

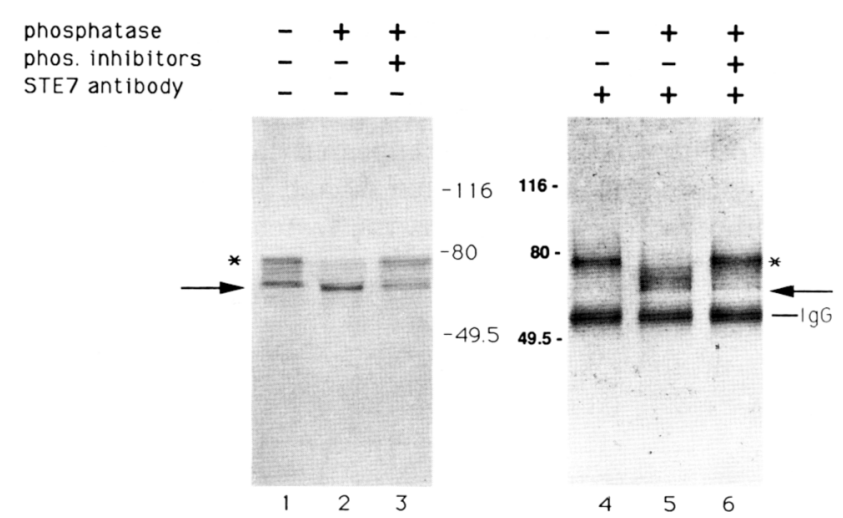

Figure 5. Treatment of the STE7 protein with calf intestinal phosphatase in the absence or presence of STE7 polyclonal antibody. The effect of phosphatase treatment on whole-cell extracts (left) or immunoprecipitates of the STE7 protein (right) was assayed by immunoblot analysis as described in Materials and methods. Whole-cell extracts were prepared from a W3031A transformant expressing STE7 with pYGU-STE7 grown in the presence of galactose for $8 \mathrm{hr}$, either in the absence of pheromone (left), or subsequently treated with $2.0 \mu \mathrm{M}$ mating factor for $5 \mathrm{~min}$ (right). Extracts were either mock treated (lanes 1,4), treated with 12 units of calf intestinal phosphatase (lanes 2,5), or treated with phosphatase in the presence of phosphatase inhibitors (lanes 3,6). The arrows indicate the position of unphosphorylated STE7 protein; the asterisks $(\star)$ indicate that of the multiply phosphorylated form of the STE7 protein. Positions of molecular mass markers $(\mathrm{kD})$ run in another lane of the same gel are indicated.

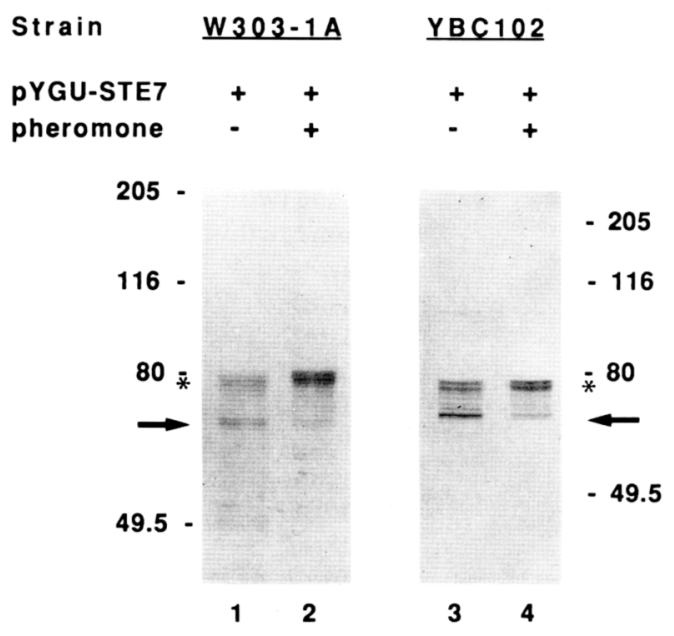

Figure 6. Effect of pheromone on the phosphorylation of STE7 protein. Whole-cell extracts (5 $\mu \mathrm{g}$ of protein per lane) were prepared, and immunoblot analysis was performed as described in Materials and methods. Each strain expressed STE7 from pYGU-STE7. Cultures of W303-1A (lanes 1,2) or the isogenic protease-deficient derivative $\mathrm{YBC} 102$ (lanes 3,4$)$ were grown in the presence of galactose for $4 \mathrm{hr}$ to induce STE7 expression. Pheromone was either not added (lanes 1,3) or added to a final concentration of $2.0 \mu \mathrm{M}$ (lanes 2,4). These cultures were incubated for $4 \mathrm{~min}$ at $30^{\circ} \mathrm{C}$ and centrifuged and frozen within $5 \mathrm{~min}$ of the addition of pheromone. The arrows indicate the position of unphosphorylated STE7 protein; the asterisks ( $\star$ ) indicate that of the multiply phosphorylated form of the STE7 protein. Positions of molecular mass markers $(\mathrm{kD})$ run in another lane of the same gel are indicated.

rylation forms in the absence of pheromone, we investigated the impact of pheromone on the distribution of these forms. STE7 protein was expressed in both the wild-type strain W303-1A and an isogenic protease-deficient derivative YBC102. Treatment with $\alpha$-factor-mating pheromone for 5 min caused the accumulation of slower-migrating phosphorylation forms of STE7 protein and the disappearance of the fastest-migrating form (Fig. 6). The phosphorylation forms were revealed most clearly in extracts derived from protease-deficient cells (lanes 3,4). Similar results were obtained with the wildtype strains YPH499 and KMY211-A. Experiments by others have shown that both the transcriptional induction of genes such as FUS1 (McCaffrey et al. 1987) and the phosphorylation of STE12 protein (Song et al. 1991) occur within $5 \mathrm{~min}$ of the addition of pheromone. Alteration of the phosphorylation state of STE7 protein is therefore correlated with mating pathway activation.

\section{STE11 1 N expression potentiates STE7 phosphorylation}

Having shown that the STE11 gene product functions upstream of the STE7 gene product in the mating pathway and, further, that phosphorylation of STE7 protein is correlated with mating pathway activation, we asked whether the dominant STE11 $\triangle N$ allele affects the distribution of STE7 phosphorylation forms. Coexpression of both STE $11 \Delta \mathrm{N}$ and STE7 protein resulted in nearly com- 
plete conversion of STE7 protein to multiply phosphorylated species (Fig. 7, lane 3). This result provides further evidence that STE7 phosphorylation is correlated with signal transmission and that STE $11 \Delta \mathrm{N}$ initiates the mating pathway upstream of STE7.

\section{STE7 phosphorylation forms are present in strains lacking other components in the mating pathway}

The mating response requires the concerted action of several components, including four putative protein kinases (Chaleff and Tatchell 1985; Courchesne et al. 1989; Elion et al. 1990, 1991; Rhodes et al. 1990). To assess the dependence of STE7 phosphorylation forms on the activity of other components in the mating pathway, we expressed STE7 protein in strains isogenic to the wild-type strain KMY211-A, lacking the STE4, STE5, STE11, or STE12 gene. In addition, we expressed STE7 protein in strains isogenic to strain YPH499, lacking either the FUS3 or KSS1 gene, or both. Immunoblot analysis revealed the presence of both unphosphorylated and multiply phosphorylated forms of STE7 protein in all of the deletion strains tested (Fig. 8). The other immunoreactive species (Fig. 8A, lane 3; Fig. 8B, lanes 1-5) are also present in extracts derived from cells grown in medium containing sucrose (Fig. 8B, lane 1, and data not shown) and, thus, are not STE7-dependent. To confirm the lack of impact on STE7 phosphorylation observed with YSC-A $\triangle$ ste11, the STE11 gene was also deleted from the chromosome in both YPH499 and W303-1A. STE7 was expressed in these alternate $\Delta$ ste 11 strains, and immunoblot analysis revealed unphosphorylated and multiply phosphorylated forms of STE7 protein that were indistinguishable from the forms observed in extracts derived

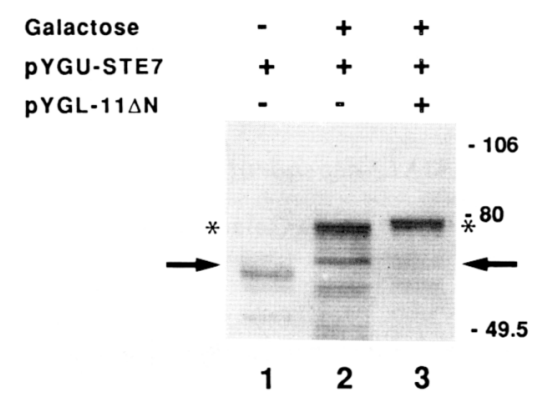

Figure 7. Expression of the STE $11 \Delta \mathrm{N}$ protein potentiates the phosphorylation of STE7 protein. The phosphorylation forms of the STE7 protein under conditions of STE $11 \Delta \mathrm{N}$ coexpression was revealed by immunoblot analysis. Whole-cell extracts $\mid 5$ $\mu \mathrm{g} /$ lane) were prepared, and immunoblot analysis was performed as described in Materials and methods. The strain W303-1A was transformed with either pYGU-STE7 (lanes 1,2) or both pYGU-STE7 and pYGL-11 $\mathrm{N}$ (lane 3). All three transformants were initially grown in medium containing $2 \%$ sucrose. For experiments presented in lanes 2 and 3 , cells were centrifuged, resuspended in medium containing $2 \%$ galactose, and grown for an additional $8 \mathrm{hr}$. Positions of molecular mass markers $(\mathrm{kD})$ run in another lane of the same gel are indicated at right. from the wild-type parent strains in the absence of pheromone (data not shown). Therefore, the other components of the mating pathway, including STE11, are not necessary for the generation of multiply phosphorylated forms of STE7 protein; nonetheless, these other components may affect the phosphorylation state of STE7 during signal transduction.

\section{Overproduction of STE7 protein does not activate STE12-dependent transcription}

Considering that multiply phosphorylated forms of STE7 are present in the absence of pheromone and that their amounts are increased by pheromone treatment, we asked whether overproduction of STE7 protein would activate the mating pathway. To examine this possibility, activation of STE12-dependent gene expression by overproduction of STE7 protein was compared to activation by pheromone treatment. The $\beta$-galactosidase reporter plasmid pUZ4 (Fig. 1C) was used to monitor STE12-dependent gene expression. Overproduction of STE7 in strains KMY211-A, YPH499, or W303-1A had no effect on STE12-dependent transcription in the absence of pheromone (Table 2). In addition, STE7 overexpression in the absence of pheromone did not initiate the phenotypes associated with pheromone-dependent activation of the mating pathway (data not shown). Finally, strains overproducing STE7 respond normally to pheromone stimulation, displaying high levels of STE12-dependent transcription (Table 2).

We also investigated whether overproduction of STE7 protein could suppress the mating defect of a strain lacking the STE11 gene. In addition, we performed the complementary experiment of expressing wild-type STE11 protein with pYGU-STE 11 in an isogenic strain lacking the STE7 gene. No diploids were formed in any of the 12 independent patch mating experiments that were performed with each strain (data not shown), demonstrating that the mating defect was not suppressed in either strain. This result is consistent with observations of others in similar experiments with high-copy plasmids (Dolan and Fields 1990), and provides further evidence that the kinases play unique roles in the mating pathway.

\section{Construction and activities of a STE7 site-directed mutant}

Finally, we investigated whether the presumed protein kinase activity of STE7 protein is required for signal propagation. A lysine at position 220 in STE7 protein corresponds to the conserved lysine found in the vast majority of serine/threonine kinases (Hanks et al. 1988). This residue was changed to an arginine, and the mutant STE7 gene was fused to the GAL1 promoter in pSE936 (Elledge et al. 1991) to create pYGU7-A220 (Fig. 1B). Similar substitutions in other kinases have been shown to impair or eliminate catalytic activity (Snyder et al. 1985; Booher and Beach 1986; Kamps and Sefton 1986; Celenza and Carlson 1989; Rhodes et al. 1990). The resulting protein, ste7-A220, was expressed in YSC- 
Figure 8. Immunoblot analysis of the STE7 protein expressed in strains lacking mating pathway components. $(A)$ Whole-cell extracts $(5 \mu \mathrm{g}$ of protein per lane) were prepared from derivatives of the wild-type strain KMY211-A. Each strain expressed STE7 protein using pYGU-STE7. Immunoblot analysis was performed as described in Materials and methods. Extracts were derived from the following strains. (Lane 1) YSC-A $\Delta$ ste4, lacking the STE4 gene; (lane 2) YSC-A $\Delta$ ste5, lacking the STE5 gene; (lane 3) YSC-ADstell, lacking the STE11 gene; (lane 4) YSC-A $\Delta$ ste12, lacking the STE12 gene. The arrow indicates the position of unphosphorylated STE7 protein; the asterisk $(\star)$ indicates that of the multiply phosphorylated form of STE7 protein. The additional cross-reactive species present in extracts derived from YSC-A $\Delta$ stell, with an apparent mass of $67 \mathrm{kD}$, is present in control extracts derived from YSC- $\Delta$ stell cells grown in sucrose (data not shown). Positions of molecular mass markers (kD) run in another lane of the same gel are indicated at right. $(B)$ Whole-cell extracts $(5 \mu \mathrm{g}$ of protein per lane) were prepared from derivatives of the wild-type strain YPH499. Each strain expressed STE7 protein with pYGU-STE7. Immunoblot analysis was performed as described in Materials and methods. Extracts were derived from the following strains. (Lane 1) YPH499, wild-type strain; (lane 2) YPH499- 4 fus3,

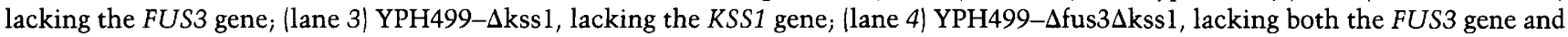

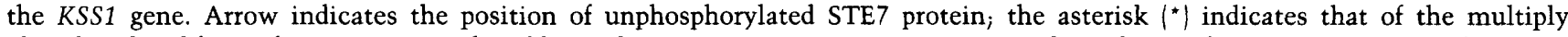
phosphorylated form of STE7 protein. The additional cross-reactive species are not STE7 dependent and are present in control extracts of each strain grown in sucrose (lane 1 and data not shown). Positions of molecular mass markers (kD) run in another lane of the same gel are indicated at left.

A $\Delta$ ste 7 for $6 \mathrm{hr}$, and the strain was tested for its ability to mate with the $\alpha$-tester strain DC17 in qualitative patch mating experiments. This strain mated very poorly, yielding only 1-16 individual diploid colonies within the patch after $96 \mathrm{hr}$ of growth on selective media (Fig. 9A). In contrast, expression of the native STE7 protein in YSC-A $\Delta$ ste7 gave dense patches within $36 \mathrm{hr}$. Expression of pYGU7-A220 in YSC-A $\Delta$ ste7 for long periods of time $(24 \mathrm{hr})$ increased the efficiency of mating two- to threefold, but the mating efficiency remained far below wildtype levels (data not shown). No diploids were observed with YSC-A $\Delta$ ste 7 patches that did not express STE7 protein. In addition, YSC-A $\Delta$ ste 7 transformants expressing ste7-A220 protein did not display any pheromone-dependent activation of STE12-dependent transcription.
These experiments indicate that STE7 protein kinase activity is important for efficient mating. The low level of mating provided by ste $7-\mathrm{A} 220 \mathrm{might}$ be the result of residual kinase activity or a secondary function such as complex formation.

To determine the relationship of the multiply phosphorylated form of STE7 protein to STE7 catalytic activity, the phosphorylation state of ste7-A220 protein in the strain YSC-A $\Delta$ ste7 was examined. Immunoblot analysis established that ste7-A220 protein is present primarily in an unphosphorylated form (Fig. 9B, lane 2). The multiply phosphorylated, slow-migrating species were not present when ste7-A220 was expressed, although a species of low immunoreactivity did appear, migrating at $\sim 73 \mathrm{kD}$, slightly faster than the prominent multiply

Table 2. Effect of overproduction of wild-type STE7 or STE11 protein on mating and STE12-dependent transcription

\begin{tabular}{|c|c|c|c|c|c|c|}
\hline \multirow[b]{2}{*}{ Strain } & \multirow[b]{2}{*}{ Deletion } & \multirow[b]{2}{*}{$\begin{array}{l}\text { Expression } \\
\text { plasmid pYGU- }\end{array}$} & \multirow[b]{2}{*}{ Mating ${ }^{\mathbf{a}}$} & \multicolumn{3}{|c|}{$\beta$-Galactosidase ${ }^{b}$} \\
\hline & & & & sucrose & galactose & $\begin{array}{l}\text { galactose } \\
+2 \mu \mathrm{M} \text { pheromone }\end{array}$ \\
\hline W303-1A & none(WT) & STE7 & ND & 7 & 7 & 235 \\
\hline W303-1A & none(WT) & STEll & ND & 7 & 7 & ND \\
\hline YPH499 & none(WT) & STE7 & +++ & 2 & 2 & 358 \\
\hline YPH499 & none(WT) & STE11 & +++ & 2 & 2 & ND \\
\hline KMY211-A & none(WT) & STE7 & +++ & $<1$ & $<1$ & 82 \\
\hline KMY211-A & none(WT) & STE11 & +++ & $<1$ & $<1$ & ND \\
\hline YSC-A $\Delta$ ste $^{\mathrm{c}}$ & Aste7 & STE7 & +++ & $<1$ & $<1$ & 54 \\
\hline YSC-A $\Delta$ ste $^{c}{ }^{c}$ & $\Delta$ ste7 & STE1l & - & $<1$ & $<1$ & ND \\
\hline YSC-A $\Delta$ ste $11^{\mathrm{c}}$ & Aste11 & STE7 & - & $<1$ & $<1$ & ND \\
\hline YSC-A $\Delta$ ste $11^{\mathrm{c}}$ & Aste11 & STE11 & +++ & $<1$ & $<1$ & ND \\
\hline
\end{tabular}

(ND) Not determined.

${ }^{a}$ Mating tests were performed by the patch method as described in Materials and methods. $1+++\mid$ Indistinguishable from wild-type. Dense patches form within $36 \mathrm{hr}$ of replica plating. (- ) No diploids form with $96 \mathrm{hr}$ of replica plating.

${ }^{\mathrm{b}} \beta$-Galactosidase assays, with the reporter plasmid pUZ4 (Fig. 1C), are in Miller units as described in Materials and methods.

${ }^{\mathrm{c}} \mathrm{KMY} 211-\mathrm{A}$ strain background 
A

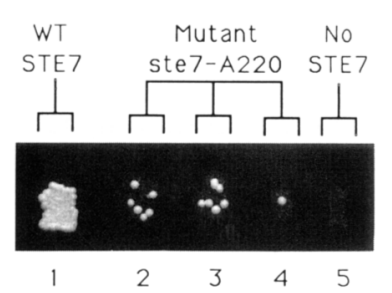

$\mathrm{B}$

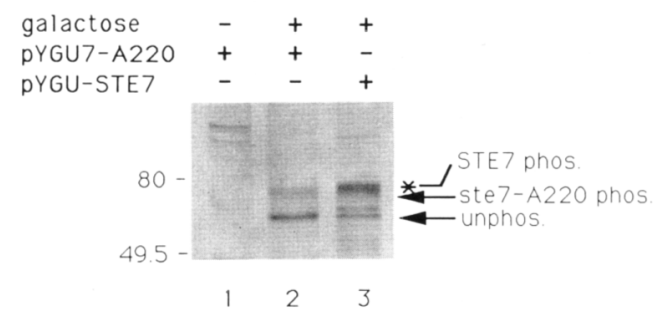

Figure 9. Phosphorylation state and mating ability of a ste 7 mutant. (A) The ability of mutant ste7-A220 protein to restore mating ability to a strain lacking the STE7 gene was determined. Patches represent diploids growing on minimal media plates, the result of successful mating of transformants of the strain YSC-A $\Delta$ ste7 with a lawn of the mating tester strain DC17. Patch 1 expressed STE7 wild-type protein from pYGUSTE7; patches 2-4 expressed ste7-A220 from pYGU7-A220; patch 5 contained the parental plasmid pYES- 1 and thus did not express any plasmid-dependent STE7 protein. $(B)$ The phosphorylation forms of ste7-A220 were revealed by immunoblot analysis. Whole-cell extracts (5 $\mu \mathrm{g} /$ lane) were prepared, and immunoblot analysis was performed as described in Materials and methods. All extracts were derived from transformants of the strain YSC-A $\Delta$ ste7. (Lane 1) A pYGU7-A220 transformant grown in medium containing $2 \%$ sucrose; (lane 2) a pYGU7A220 transformant expressing ste7-A220 protein; (lane 3) a pYGU-STE7 transformant expressing wild-type STE7 protein. Positions of molecular mass markers $(\mathrm{kD})$ run in another lane of the same gel are indicated at left.

phosphorylated bands observed with wild-type STE7 protein. In addition, overexpression of ste7-A220 in the wild-type strains KMY211A and W303-1A gave immunoreactive species identical in mobility to those produced in YSC-A $\Delta$ ste7 (data not shown), indicating that the presence of the wild-type STE7 has little or no effect on the phosphorylation state of overexpressed ste7-A220 protein.

\section{Discussion}

We have discovered a dominant allele of the STE11 kinase whose expression causes constitutive activation of the mating pathway. Characterization of this dominant mutation shed light on the structure and function of the STE11 gene product and clarified its relationship to other mating pathway components. The dominant mutation lacks the amino-terminal 351 amino acids present in wild-type STE11 protein but retains the conserved kinase subdomains in the remaining carboxy-terminal 366 amino acids (Hanks et al. 1988; Rhodes et al. 1990). In the absence of pheromone, the mutant STE11 protein
(STE1 $1 \Delta N$ ) activates the mating pathway to a level equal to or greater than that in the presence of pheromone, suggesting that the amino terminus of STE11 acts as a regulatory region that inhibits the activity of the carboxy-terminal catalytic domain. During signaling, upstream components in the mating pathway may interact with this regulatory domain directly or generate a second messenger that influences the function of the regulatory domain.

We have used STE11 $\mathrm{N}$ to determine the functional order of several components of the mating pathway whose epistatic relationships were previously unknown. STE1 $1 \Delta \mathrm{N}$ expression restores a significant level of mating ability to strains lacking either the STE4 or STE5 gene but not to strains lacking the STE7 or STE12 genes. We conclude that the STE4 and STE5 gene products function upstream of the STE11 gene product, and the STE7 and STE12 gene products function downstream of the STE11 protein. These results, along with those of others (Dietzel and Kurjan 1987; Miyajima et al. 1987; Blinder et al. 1989; Dolan and Fields 1990), are consistent with an order of execution (in MATa cells) as follows: $\alpha$-factor, STE2, GPA1(SCG1), STE4, STE5, STE11, STE7, $S T E 12$, transcriptional induction. Although this order assumes that the action of the gene products are sequential, more complex interactions are also consistent with the data (Fig. 10).

Our experiments also shed light on the point of action of the FUS3 and KSS1 kinases in the signaling pathway. Expression of the dominant allele of STE11 induced high levels of STE12-dependent transcription in strains lacking the FUS3 or the KSS1 gene but not in a strain lacking both the FUS3 and KSS1 genes. This result is consistent with FUS3 and KSS1 serving redundant roles, in concert with, or following the action of, STE11 protein. Alternatively, these kinases could be required for the synthesis or activity of a pathway component.

We have observed both unphosphorylated and multiply phosphorylated forms of STE7 protein and have investigated both the origin and significance of these forms. In the absence of pheromone, multiply phosphorylated forms of STE7 protein are present in strains lacking each of the kinases involved in the mating pathway, including the $\Delta$ fus $3 \Delta k s s 1$ double deletion strain. This result requires that multiply phosphorylated forms of STE7 arise from STE7 autophosphorylation and/or the direct phosphorylation of STE7 by a novel kinase. Experiments with the STE7 mutant ste7-A220 indicate that autophosphorylation may play an important role: The vast majority of ste 7-A220 protein is unphosphorylated, and the scarce ste7-A220 phosphorylated form does not comigrate with the multiply phosphorylated species observed with wild-type STE7 protein. Components upstream in the pheromone response pathway might influence the rate of STE7 autophosphorylation during signal transmission by one of several mechanisms, including the generation of second messengers or the direct phosphorylation of STE7 protein by an upstream kinase. Alternatively, a novel kinase may phosphorylate STE7 protein multiple times and be potentiated by another path- 


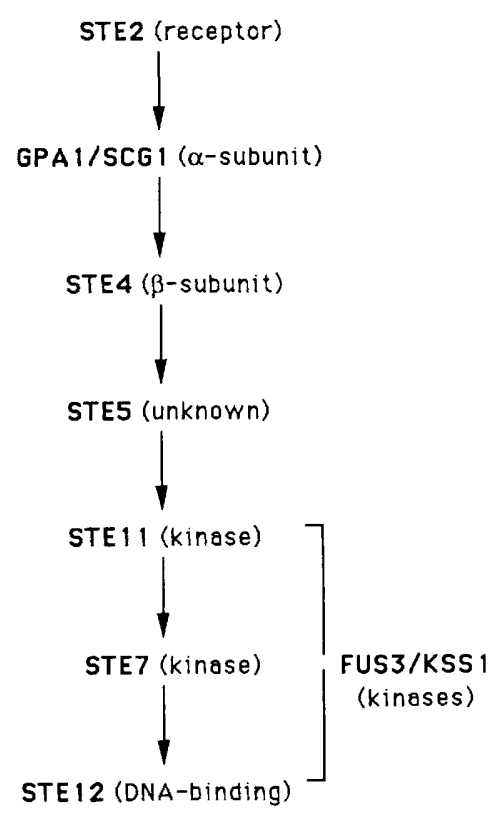

Figure 10. Order of action of mating pathway gene products. This schematic representation of the order of action of the mating pathway gene products reflects the data presented here and the data of others (Dietzel and Kurjan 1987; Miyajima et al. 1987; Blinder et al. 1989; Dolan et al. 1989|. Although the execution point of the FUS3 and KSS1 kinases appears to be downstream of the STE11 kinase, its precise location remains undefined (brackets). The model does not imply that the interactions are necessarily direct, nor does it exclude the possibility of more complex interactions.

way component. Experiments with purified STE7 protein in vitro are needed to establish the possible role of STE7 autophosphorylation in signal propagation.

Three lines of evidence indicate that STE7 phosphorylation plays a role in pheromone response: (1) Although both unphosphorylated and multiply phosphorylated forms of STE7 protein are present in the absence of pheromone activation, multiply phosphorylated forms of STE7 protein accumulate upon exposure to mating pheromone; (2) this accumulation is temporally competent, occurring on the same time scale as other responses to pheromone such as transcriptional induction of the FUS1 gene (McCaffrey et al. 1987) and the phosphorylation of the transcriptional activator STE12 (Song et al. 1991); and (3) expression of the dominant allele of STE11 causes nearly quantitative conversion of STE7 protein to multiply phosphorylated forms.

The correlation of STE7 phosphorylation with mating pathway activation can be interpreted in at least two ways. One interpretation is that multiply phosphorylated forms of STE7 protein are active signal transducers, but the unphosphorylated form of STE7 inhibits signal transduction. The role of upstream components is to induce the conversion of STE7 protein from the unphosphorylated to multiply phosphorylated species, thus relieving the antagonistic action of unphosphorylated STE7. This interpretation is consistent with our obser- vation that overproduction of STE7 protein does not activate the mating pathway, eliminating the possibility that an increase in the amount of multiply phosphorylated STE7 protein alone can initiate signaling. Alternatively, the repertoire of multiply phosphorylated forms of STE7 in pheromone-stimulated cells may differ from the forms present in unstimulated cells. Thus, there may be unique phosphorylation forms of STE7 protein generated in the presence of pheromone that could not be distinguished in the immunoblot analysis experiments presented here.

A second interpretation is that phosphorylation of STE7 protein is part of the adaptive response to pheromone (Ciejek and Thorner 1979; Sprague and Herskowitz 1981; Courchesne et al. 1989; Cole and Reed 1991; Irie et al. 1991). According to this interpretation, the phosphorylation of STE7 is important in down-regulating or otherwise altering STE7 protein kinase activity. This model requires the involvement of unphosphorylated STE7 protein in signal propagation, with multiply phosphorylated forms of STE7 having altered substrate specificities or impaired catalytic activities. Further experiments on STE7 phosphorylation, both in vivo and in vitro, are needed to distinguish between these and other potential models.

\section{Materials and methods}

Yeast strains and genetic methods

All strains used in this study (Table 3), except mating testers, are either derivatives of W303-1A (gift of S. Fields) KMY211-A (gift of K. Matsumoto), or YPH499 (gift of P. Hieter). CB023 is a W303-1A derivative lacking the three major vacuolar proteases (Brenner and Fuller 1992). The protease-deficient strain lacking the BAR1(SST1) gene, YBC102, was prepared from CB023 by one-step gene replacement (Rothstein 1983) with the SalIEcoRI fragment of pJGsst 1 (Reneke et al. 1988). Selection of ura3 recombinants was accomplished with 5 '-fluoro-orotic acid (5'-FOA) (Boeke et al. 1984), and replacement was verified by Southern blot analysis (Southern 1975). Strains lacking the STE4, STE5, STE7, STE11, and STE12 genes are all derivatives of KMY211-A and were prepared and kindly provided by K. Sugimoto. Confirmation of their construction (mating complementation and Southern blot analysis) was performed in collaboration with $\mathrm{K}$. Sugimoto. The derivative lacking the STE4 gene, YSC-A $\Delta$ ste4, was prepared by one-step gene replacement with the 3.9-kb PstI-PstI fragment of p4-121 (gift of V. MacKay). Correct integrants were confirmed by complementation of their mating defect with the wild-type gene with pL19 (Whiteway et al. 1990). The derivative lacking the STE5 gene, YSC-A $\Delta$ ste5, was prepared by one-step gene replacement with pSF32 (gift of V. Mackay). Correct integrants were confirmed by complementation of the mating defect with the wild-type STE5 gene with $\mathrm{pHO} 22$ (gift of K. Sugimoto). The derivative lacking the STE7 gene, YSC-A $\Delta$ ste7, was prepared by one-step gene replacement with pNCl13 (constructed by B. Errede). Correct integrants were confirmed by complemetation of the mating defect with the wild-type gene with pYGU-STE7 (see below) and Southern blot analysis. The derivative lacking the STE11 gene, YSCA $\Delta$ stell, was prepared by one-step gene replacement with the 2.6-kb XbaI fragment from pNC202 (Rhodes et al. 1990). Correct integrants were confirmed by complemetation of the mating defect with the wild-type gene using pYGU-STE11 (see be- 
Table 3. Yeast strains used in this study

\begin{tabular}{|c|c|c|}
\hline Strains & Genotype & Source \\
\hline KMY211-A & a his3 leu2 ura3 trp1 & K. Matsumoto \\
\hline YSC-A $\Delta$ ste 4 & a his3 leu2 ura3 trp1 ste $4:: L E U 2^{a}$ & this study, with K. Sugimoto \\
\hline YSC-A $\Delta$ ste 5 & a his3 leu2 ura3 trp1 ste5::LEU2 ${ }^{a}$ & this study, with K. Sugimoto \\
\hline YSC-A $\Delta$ ste 7 & a his3 leu2 ura3 trp1 ste $7:: L E U 2^{a}$ & this study, with K. Sugimoto \\
\hline YSC-A $\Delta$ stell & a his3 leu2 ura3 trp1 ste11::ura3 ${ }^{a}$ & this study, with K. Sugimoto \\
\hline YSC-A $\Delta$ ste 12 & a his3 leu2 ura3 trp1 ste $12:: L E U 2^{\mathrm{a}}$ & this study, with K. Sugimoto \\
\hline YPH499 & a his3-4200 leu2-41 ura3-52 trp1- $\Delta 63$ ade2-101 lys2-801 b & D. $\mathrm{Ma}$ and $\mathrm{J}$. Thorner \\
\hline YPH499- $\Delta$ fus3 & $\begin{array}{l}\text { a his3- } \Delta 200 \text { leu2- } \Delta 1 \text { ura3-52 trp1- } \Delta 63 \text { ade2-101 lys2-801 } \\
\text { fus3::LEU2 }\end{array}$ & D. Ma and J. Thorner \\
\hline YPH499- $\Delta$ kss 1 & $\begin{array}{l}\text { a his3- } \Delta 200 \text { leu2- } \Delta 1 \text { ura3-52 trp1- }-63 \text { ade2-101 lys2-801 } \\
\text { kss1::HIS3 }\end{array}$ & D. Ma and J. Thorner \\
\hline YPH499- $\Delta$ fus3 $\Delta$ kss 1 & 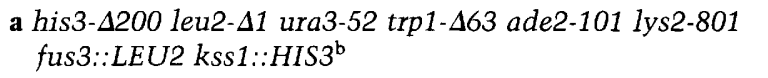 & D. Ma and J. Thorner \\
\hline W303-1A & a his3-15 leu2-3,112 ura3-1 trp1-1 ade2-1 can1-100 & S. Fields \\
\hline YBCl02 & $\begin{array}{l}\text { a pep } 4:: H I S 3 \text { prb1 }:: \text { LEU2 prc1 }:: H I S G \text { bar } 1:: H I S G \\
\text { can1-100 ade2-101 trp1-1 ura3 his3-15 leu2-3,112 }\end{array}$ & this study \\
\hline NNY19 & a his3 leu2 trp1 lys2 FUS1-lacZ::LEU2 & K. Matsumoto laboratory \\
\hline DC14 & a his1 & R. Fuller \\
\hline $\mathrm{DCl} 17$ & $\alpha$ his1 & R. Fuller \\
\hline
\end{tabular}

${ }^{\mathrm{a}} \mathrm{KMY} 211-\mathrm{A}$ strain background.

bYPH499 strain background.

'W303-1A strain background.

low). ura 3 revertants were selected by growth on $5^{\prime}$-FOA plates (Boeke et al. 1984). The derivative lacking the STE12 gene, YSCA $\Delta$ ste 12, was prepared by one-step gene replacement with the SphI-SacI fragment of pSUL16 (Fields and Herskowitz 1987). Correct integrants were confirmed by complemetation of the mating defect with the wild-type STE12 gene using pOF22 (Dolan and Fields 1990) and by Southern blot analysis.

All media were prepared as described in Sherman et al. (1979). Transformations of yeast strains were accomplished by the use of $\mathrm{LiCl}$ (Ito et al. 1983). Mating tests were performed using a modification of the patch test method (Sprague and Herskowitz 1981). Patch tests involving the expression of proteins from the GAL1 promoter were performed by growing patches on appropriate plates containing minimal medium and $2 \%$ sucrose. Matings were performed by replica-plating the patches to plates containing rich media (YP) and $2 \%$ galactose, with mating tester (strain DC17) lawns, and growing for $8 \mathrm{hr}$ at $30^{\circ} \mathrm{C}$ before replicaplating to selective plates containing minimal medium and $2 \%$ glucose. Experiments involving mating pheromone were done with $\alpha$-mating factor purchased from Penninsula Laboratories (no. 8360).

\section{Plasmids}

The plasmid pBSCR-STE7 containing the STE7 gene in Bluescript (BSCR, Stratagene) was prepared by cloning the $1.7-\mathrm{kb}$ STE7 BanII-HindIII fragment from pYNS7 (gift of K. Sugimoto) into the XhoI-HindIII polylinker sites of BSCR and repairing the 5 '-coding region with a 56 -bp/48-bp XhoI-BanII oligonucleotide. This oligonucleotide also created an NdeI site at the initiator codon flanked by an EcoRI site. The bacterial expression plasmid pET-STE7 was prepared by cloning the $1.8-\mathrm{kb}$ NdeIBamHI fragment from pBSCR-STE7 into the NdeI-BamHI site in pET11-A (Novagen). The galactose-inducible yeast overproduction vector $\mathrm{pYGU-STE7}$ was prepared by cloning the $1.8 \mathrm{-kb}$ KpnI-NotI fragment from pBSCR-STE7 into the KpnI-NotI site of pYES-1 $2 \mu$ origin, URA3, GAL1 promoter; InVitrogen).
Site-directed mutagenesis of STE7, replacing the lysine at position 220 with an arginine, was performed by direct oligonucleotide replacement of the 42-bp/34-bp AflIII-BstXI fragment of STE7 with a double-stranded oligonucleotide containing a single-base-pair substitution (AAA $\rightarrow$ AGA). The dephosphorylated 2.3-kb AfIIII-BstXI fragment of pBSCR-STE7, the 1.3-kb AfIIII fragment of pBSCR-STE7, and the phosphorylated double-stranded oligonucleotide were ligated to form pBC7-A220. The construction was confirmed by sequencing with the dideoxy chain termination method (Sanger et al. 1977). The sitedirected mutant was placed under control of the galactose-inducible GAL1 promoter by ligation of the $1.8 \mathrm{-kb} X b a \mathrm{I}-X$ hoI STE7 fragment from $\mathrm{pBC7}-\mathrm{A} 220$ to the $7.8 \mathrm{~kb}$ vector $\mathrm{XbaI}-$ Xhol fragment of pSE936 (Elledge et al. 1991), resulting in pYGU7-A220.

The STE11 gene was cloned from yeast genomic DNA by the polymerase chain reaction (PCR) procedure (Saiki et al. 1988) with Taq thermostable DNA polymerase (Cetus) and the oligonucleotide primers 5'-CCCGAATTCGTCGACCATATGGAACAGACACAAACAGCAGA- $3^{\prime}$ and $5^{\prime}$-CCCGGATCCTCTAGATGATTACTTAATCAGCGTAATTGA-3'. A 2.4-kb DNA, the sole PCR product produced, was digested with $B a m H I$ and $X b a I$ and cloned into the BamHI-XbaI site of pSE936 (Elledge et al. 1991) to give the galactose-inducible expression vector pYGU-STE11. Four independent PCR clones were tested in the mating and transcription experiments described in the text.

The plasmid containing the amino-terminal truncation of STE11 under the control of the GAL1 promoter was isolated from a genetic screen by S. Ramer (S. Ramer and R. Davis, in prep.). A plasmid with a pSE936 (Elledge et al. 1991) backbone (URA3, CEN4, GAL1 promoter), which hybridized with a STE11 probe, was provided by S. Ramer for further analysis in the present study. This STE11-containing plasmid was found to contain a deletion in the $5^{\prime}$-coding region of STE11 and was therefore named pYGU-1 $1 \Delta$ N. Sequencing (Sanger et al. 1977) with an oligonucleotide primer corresponding to nucleotides 
764-788 of the GAL1 promoter (Johnston and Davis 1984) determined the $5^{\prime}$ end of this STE11 allele. The sequence of the junction between the GAL1 promoter and STE11 is 5'-(AAACCTCTA)|[GCCGAATTCCTCGAGCTACGTCAGGG]<AAGGCTAAGC >-3', with ( ), [ ], and <> representing the $3^{\prime}$ end of the GAL1 promoter, the DNA linker, and the $5^{\prime}$ end of the STE11 gene, respectively. The last nucleotide of the GAL1 promoter included is nucleotide 851 (Johnston and Davis 1984), and the first nucleotide of STE11 present is nucleotide 1051 (Rhodes et al. 1990). A LEU2 version of this plasmid (pYGL-STE $11 \Delta \mathrm{N}$ ) was prepared by cloning the $1.8 \mathrm{-kb}$ EcoRI$X b a I$ fragment of pYGU- $11 \Delta \mathrm{N}$ into the SacI-XbaI polylinker sites of pMW20LEU2 (CEN4 LEU2 GAL1/10 promoter; kindly provided by $\mathrm{H}$. Ziegler and $\mathrm{M}$. Walberg/ by use of the phosphorylated oligonucleotide 5'-AATTAGCT-3' to repair the EcoRISacI overhang.

STE $11 \Delta \mathrm{N}$ was overproduced in $E$. coli with the glutathione $S$-transferase fusion vector pGEX-3X (Pharmacia). STEl $1 \Delta N$ was modified by PCR to contain a BamHI site at the $5^{\prime}$ end and a BgIII site at the $3^{\prime}$ end. This fragment was cloned in-frame into the BamHI site of pGEX-3X to form pGEX-STE11 1 N.

The reporter plasmid pUZ4 (CEN4 TRP1) containing three consensus-binding sites for the transcription factor STE12 upstream of the $\beta$-galactosidase gene was prepared with the following double-stranded oligonucleotides /gift of K. Sugimoto): 5'-CTAGATGAAACAAACATGAAACATCTGATGAAA-

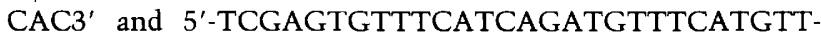
TGTTTCAT-3'. This oligonucleotide was hybridized and cloned into the $X h o I-X b a I$ site of $\mathrm{pCZ} \Delta$ (Buchman and Kornberg $1990)$ to create pCZ4. pUZ4 is a vector containing a pUN20 backbone (TRP1 CEN4 SUP11), the 3' end of the lacZ gene from pMC1871, and the XbaI-ClaI fragment of pCZ4 containing the STE12 UAS, the CYC1 promoter, and the $5^{\prime}$ end of the lacZ gene.

\section{Purification of STE7 protein}

BL21(DE3) cells (Novagen) containing the lysozyme-expressing plasmid pLysS (Novagen) were transformed with pETIlASTE7. The transformant was grown at $37^{\circ} \mathrm{C}$ in $\mathrm{LB}$ medium 12 liters) containing $100 \mu \mathrm{g} / \mathrm{ml}$ of ampicillin and $25 \mu \mathrm{g} / \mathrm{ml}$ of chloramphenicol to an $\mathrm{OD}_{600}$ of 0.7 . The culture was induced with $0.5 \mathrm{~mm}$ isopropylthiogalactoside and grown for an additional 2 $\mathrm{hr}$. The cells were harvested by centrifugation at $5000 \mathrm{~g}$ for 10 min, washed with $100 \mathrm{ml}$ of $20 \mathrm{mM}$ HEPES (pH 7.5), and suspended in $100 \mathrm{ml}$ of buffer A [20 mM HEPES at $\mathrm{pH} 7.5,10 \%$ glycerol, $10 \mathrm{mM} \beta$-mercaptoethanol, $1 \mathrm{mM}$ EDTA , $2 \mu \mathrm{g} / \mathrm{ml}$ of chymostatin, $2 \mu \mathrm{M}$ pepstatin A, $0.6 \mu \mathrm{M}$ leupeptin, $2 \mathrm{mM}$ benzamidine, $1 \mathrm{mM}$ phenylmethylsulphonyl flouride (PMSF)], containing $400 \mathrm{~mm} \mathrm{NaCl}$. The suspension was lysed by sonication at $4^{\circ} \mathrm{C}$ and centrifuged at $10,000 \mathrm{~g}$ for $10 \mathrm{~min}$. The pellet, containing the majority of STE7 protein, was suspended in $5 \mathrm{ml}$ of buffer $\mathrm{A}$ containing $0.5 \%$ Triton $\mathrm{X}-100$, incubated at $4^{\circ} \mathrm{C}$ for 10 min, and centrifuged at $10,000 \mathrm{~g}$ for $10 \mathrm{~min}$ at $4^{\circ} \mathrm{C}$. The pellet was washed four additional times in the same manner and suspended in $1 \mathrm{ml}$ of buffer A containing $50 \mathrm{mM} \mathrm{NaCl}$. The resulting STE7 protein was judged to be $\sim 80 \%$ pure by SDS-PAGE electrophoresis.

\section{Purification of STE11 protein}

XL1 cells (Stratagene) were transformed with pGEX-STE $11 \Delta N$. The STE11 fusion protein was induced and purified by the same protocol as was the STE7 protein. The resulting STE11 fusion protein was judged to be $\sim 90 \%$ pure by SDS-PAGE electrophoresis.

\section{Antisera}

Approximately 2 mg of purified STE7 was subjected to electrophoresis in a 10\% SDS-polyacrylamide gel (Laemmli 1970). The gel was stained with Coomassie brilliant blue R-250, and a slice containing STE7 was removed. A rabbit was initially immunized with $0.5 \mathrm{mg}$ of STE7 and then boosted every 21 days with $0.25 \mathrm{mg}$ of STE7 protein for a total of four boosts. The antisera used in this study were taken 10 days after the second boost. All antibody preparations were performed by BabCO (Berkeley, CA). Essentially the same protocol was employed for the preparation of STE11 polyclonal antisera, by use of $2 \mathrm{mg}$ of recombinant STE11-GST fusion protein.

\section{Immunoblot analysis}

For the analysis of STE7 phosphorylation in strains containing pYGU-STE7, whole-cell extracts were prepared as described below for $\beta$-galactosidase assays, except buffer A also contained phosphatase inhibitors $15 \mathrm{~mm}$ sodium fluoride, $5 \mathrm{~mm}$ sodium phosphate, $10 \mathrm{mM}$ sodium pyrophosphate, $10 \mathrm{~mm}$ sodium molybdate, $1 \mathrm{~mm}$ EGTA). Whole-cell extracts (5 $\mu \mathrm{g} / \mathrm{gel}$ lane) were subjected to electrophoresis in a $10 \%$ SDS-polyacrylamide gel and transferred to nitrocellulose filters (Towbin et al. 1979). The STE7 polyclonal antibody (1:1000 dilution) was used as the primary antibody, and Bio-Rad goat anti-rabbit IgG conjugated to alkaline phosphatase $(1: 2000$ dilution) was used as the secondary antibody. A similar protocol, omitting the phosphatase inhibitors, was followed for the analysis of STE1l protein.

\section{Phosphatase treatments}

Whole-cell extract ( $5 \mu \mathrm{g}$ of protein in $\sim 1 \mu \mathrm{l}$ ) was diluted with $8.5 \mu \mathrm{l}$ of phosphatase buffer $(100 \mathrm{mM}$ Tris- $\mathrm{HCl}$, at $\mathrm{pH} 9.6,2 \mathrm{mM}$ $\mathrm{MgCl}_{2}, 0.1 \mathrm{~mm} \mathrm{ZnCl}$ ), followed by the addition of 12 units of calf intestinal phosphatase (Boehringer Mannheim; $24 \mathrm{U} / \mu \mathrm{l}$ ) to all but mock-treated samples. Samples containing phosphatase inhibitors were supplemented with $l \mu l$ of a $10 \times$ phosphatase inhibitor cocktail (final concentrations, $5 \mathrm{~mm}$ sodium fluoride, $5 \mathrm{~mm}$ sodium phosphate, $10 \mathrm{~mm}$ sodium pyrophosphate, $10 \mathrm{~mm}$ sodium molybdate, $5 \mathrm{~mm}$ EDTA, $5 \mathrm{~mm}$ EGTAl. Mixtures were incubated for $1 \mathrm{hr}$ at $37^{\circ} \mathrm{C}$, terminated with $10 \mu \mathrm{l}$ of SDS gel loading buffer, and boiled for $2 \mathrm{~min}$ before gel electrophoresis.

The immune complexes of STE7 used for dephosphorylation experiments were prepared as follows: Whole-cell extract (100 $\mu \mathrm{g}$ of protein) was diluted to a final volume of $200 \mu \mathrm{l}$ in buffer $\mathrm{B}(20 \mathrm{~mm}$ Tris- $\mathrm{HCl}$ at $\mathrm{pH} 7.5,1 \mathrm{~mm}$ EDTA, $5 \%$ glycerol, $0.5 \mathrm{~mm}$ dithiothreitol, $2 \mu \mathrm{g} / \mathrm{ml}$ of chymostatin, $2 \mu \mathrm{M}$ pepstatin A, 0.6 $\mu \mathrm{M}$ leupeptin, $2 \mathrm{mM}$ benzamidine, $1 \mathrm{mM}$ PMSF) containing 100 $\mathrm{mM} \mathrm{NaCl}$, and STE7 polyclonal antibody $(4 \mu \mathrm{l} ; 1: 500$ final dilution) was added followed by a 2 -hr incubation on a rotator at $4^{\circ} \mathrm{C}$. Protein A beads $[50 \mu 1$ of a $10 \%$ solution in buffer B (with $50 \mathrm{~mm} \mathrm{NaCl}$ and $0.2 \mathrm{mg} / \mathrm{ml}$ of BSA)] were added and incubated for an additional hour. The suspension was centrifuged at $4000 \mathrm{~g}$ for $2 \mathrm{~min}$, and the pellet was washed twice with $0.5 \mathrm{ml}$ of buffer $B$ containing $1 \mathrm{M} \mathrm{NaCl}$ and $0.5 \%$ Triton X-100, with each rinse separated by a $10-\mathrm{min}$ incubation and a centrifugation at $4000 \mathrm{~g}$. The final wash was performed with buffer B containing $50 \mathrm{~mm}$ $\mathrm{NaCl}$ and no Tris. Dephosphorylation experiments $(10 \mu l$ final volume per assay/ were performed as indicated above on the immune complexes attached to the protein $\mathrm{A}$ beads. Following two washes with $0.5 \mathrm{ml}$ of buffer $\mathrm{B}$ containing $1 \mathrm{M} \mathrm{NaCl}$, the beads were suspended in $20 \mu l$ of $2 \times$ SDS gel loading buffer, and boiled for $2 \mathrm{~min}$ before gel electrophoresis.

\section{$\beta$-Galactosidase assays}

Activation of pheromone-inducible genes was quantified by 
$\beta$-galactosidase assays with the reporter plasmid pUZ4 [CEN4 TRP1 ARS). Strains containing pUZ4 (alone or in combination with galactose-inducible plasmids) were grown in $50 \mathrm{ml}$ of synthetic medium containing the appropriate amino acids, $2 \%$ sucrose, and $0.1 \%$ glucose to an $\mathrm{OD}_{600}$ of 0.5 . The cell suspension was centrifuged at $5000 \mathrm{~g}$ for $10 \mathrm{~min}$, washed with sterile water, resuspended in $100 \mathrm{ml}$ of rich medium (YP) containing $2 \%$ galactose, and grown for an additional $8 \mathrm{hr}$. Cells were harvested and suspended in $1.0 \mathrm{ml}$ of buffer B containing $400 \mathrm{~mm} \mathrm{NaCl}$. The cells were disrupted by beating with glass beads for $9 \mathrm{~min}$ at $4^{\circ} \mathrm{C}$. The extract was centrifuged at $13,000 \mathrm{~g}$ for $10 \mathrm{~min}$, and the supernatant was centrifuged again at $13,000 \mathrm{~g}$ for $10 \mathrm{~min}$. $\beta$-Galactosidase activities, determined as described by Miller (1972), are given in units per microgram of protein in the wholecell extract.

\section{Acknowledgments}

We thank Katsunori Sugimoto for strains, plasmids, and helpful discussions. We also thank Robert Fuller and Charles Brenner for CB010, Stan Fields for strains and pSUL16, Helge Ziegler and Mark Walberg for pMW20L, Leslie Bell and Vivian MacKay for disruption plasmids, and Malcom Whiteway for pL19. Kunihiro Matsumoto kindly contributed plasmids and strains. Elaine Elion, William Courchesne, Phil Hieter, Doreen Ma, and Jeremy Thorner graciously provided strains and plasmids for work involving KSSI and FUS3. B.R.C. received a graduate fellowship from the National Institutes of Health (NIH). This work was supported by NIH grant GM-36659 to R.D.R.

The publication costs of this article were defrayed in part by payment of page charges. This article must therefore be hereby marked "advertisement" in accordance with 18 USC section 1734 solely to indicate this fact.

\section{References}

Bender, A. and G.F. Sprague Jr. 1986. Yeast peptide pheromones, a-factor and $\alpha$-factor, activate a common response mechanism in their target cells. Cell 47: 929-937.

Blinder, D., S. Bouvier, and D.D. Jenness. 1989. Constitutive mutants in the yeast pheromone response: Ordered function of the gene products. Cell 56: 479-486.

Boeke, J.D., F. LaCroute, and G.R. Fink. 1984. A positive selection for mutants lacking orotidine 5 '-phosphate decarboxylase activity in yeast: $5^{\prime}$-Fluoro-orotic acid resistance. Mol. Gen. Genet. 197: 345-346.

Booher, R. and D. Beach. 1986. Site-specific mutagenesis of $c d c 2$, a cell cycle control gene of the fission yeast Schizosaccharomyces pombe. Mol. Cell. Biol. 6: 3523-3530.

Brenner, C. and R. Fuller. 1992. Structural and enzymatic characterization of a purified prohormone-processing enzyme: Secreted, soluble Kex2 protease. Proc. Natl. Acad. Sci. 89: 922-926.

Buchman, A.R. and R.D. Kornberg. 1990. A yeast ARS-binding protein activates transcription synergistically in combination with other weak activation factors. Mol. Cell. Biol. 10: $887-897$.

Bucking-Throm, E., W. Duntze, L.H. Hartwell, and T.R. Manney. 1973. Reversible arrest of haploid cells at the initiation of DNA synthesis by a diffusable sex factor. Exp. Cell Res. 76: 99-110.

Celenza, J.L. and M. Carlson. 1989. Mutational analysis of the Saccharomyces cerevisiae SNFI protein kinase and evidence for functional interaction with the SNF4 protein. Mol. Cell. Biol. 9: 5034-5044.

Chaleff, D.T. and K. Tatchell. 1985. Molecular cloning and char- acterization of the STE7 and STE11 genes of Saccharomyces cerevisiae. Mol. Cell. Biol. 5: 1878-1886.

Ciejek, E. and J. Thorner. 1979. Recovery of S. cerevisiae a cells from Gl arrest by $\alpha$-factor pheromone requires endopeptidase action. Cell 16: 623-635.

Cigan, A.M. and T.F. Donahue. 1987. Sequence and structural features associated with translational initiator regions in yeast-A review. Gene 59: 1-18.

Cole, G.M. and S.I. Reed. 1991. Pheromone-induced phosphorylation of $G$ protein $\beta$ subunit in $S$. cerevisiae is associated with an adaptive response to mating pheromone. Cell 64: 703-716.

Cole, G.M., D.E. Stone, and S.I. Reed. 1990. Stoichiometry of G protein subunits affects the Saccharomyces cerevisiae mating pheromone signal transduction pathway. Mol. Cell. Biol. 10: $510-517$.

Courchesne, W.E., R. Kunisawa, and J. Thorner. 1989. A putative protein kinase overcomes pheromone-induced arrest of cell cycling in S. cerevisiae. Cell 58: 1107-1119.

Cross, F., L.H. Hartwell, C. Jackson, and J.B. Konopka. 1988. Conjugation in Saccharomcyes cerevisiae. Annu. Rev. Cell. Biol. 4: 429-457.

Dietzel, C. and J. Kurjan. 1987. The yeast SCG1 gene: A G -like $^{-19}$ protein implicated in the a- and $\alpha$-factor response pathway. Cell 50: 1001-1010.

Dixon, R.A.F., B.K. Kobilka, D.J. Strader, J.L. Benovic, H.G. Dohlman, T. Frielle, M.A. Bolanowski, C.D. Bennet, E. Rands, R.E. Diehl, R.A. Mumford, E.E. Slater, I.S. Sigal, M.S. Caron, R.J. Lefkowitz, and C.D. Strader. 1986. Cloning of the gene and cDNA for mammalian $\beta$-adrenergic receptor and homology with rhodopsin. Nature 321: 75-79.

Dolan, J.W. and S. Fields. 1990. Overproduction of the yeast STE12 protein leads to constitutive transcriptional induction. Genes \& Dev. 4: 492-502.

Dolan, J.W., C. Kirkman, and S. Fields. 1989. The yeast STE12 protein binds to the DNA sequence mediating pheromone induction. Proc. Natl. Acad. Sci. 86: 5703-5707.

Duntze, W., V. MacKay, and T.R. Manney. 1970. Saccharomyces cerevisiae: A diffusable sex factor. Science 168: 14721473.

Elion, E.A., P.L. Grisafi, and G.R. Fink. 1990. FUS3 encodes a cdc2 + /CDC28-related kinase required for the transition from mitosis into conjugation. Cell 60: 649-664.

Elion, E.A., J.A. Brill, and G.R. Fink. 1991. FUS3 represses CLN1 and CLN2 and in concert with KSS1 promotes signal transduction. Proc. Natl. Acad. Sci. 88: 9392-9396.

Elledge, S.J., J.T. Mulligan, S.W. Ramer, M. Spottswood, and R.W. Davis. 1991. $\lambda$ YES: A multifuctional cDNA expression vector for the isolation of genes by complementation of yeast and Escherichia coli mutations. Proc. Natl. Acad. Sci. 88: 1731-1735.

Errede, B. and G. Ammerer. 1989. STE12, a protein involved in cell type-specific transcription and signal transduction in yeast, is part of protein-DNA complexes. Genes \& Dev. 3: 1349-1361.

Federman, A., B. Conklin, K. Schrader, R. Reed, and H. Bourne. 1992. Hormonal stimulation of adenylyl cyclase through $\mathrm{G}_{\mathbf{i}^{-}}$ protein $\beta \gamma$ subunits. Nature 356: 159-161.

Fields, S. and I. Herskowitz. 1987. Regulation by the yeast mating-type locus of $S T E 12$, a gene required for cell-type-specific expression. Mol. Cell. Biol. 7: 3818-3821.

Gilman, A. 1987. G proteins: Transducers of receptor-generated signals. Annu. Rev. Biochem. 56: 615-649.

Hanks, S.K., A.M. Quin, and T. Hunter. 1988. The protein kinase family: Conserved features and deduced phylogeny of the catalytic domains. Science 241: 42-52. 
Hartwell, L. 1973. Synchronization of haploid yeast cell cycles, a prelude to conjugation. Exp. Cell Res. 76: 111-117.

. 1980. Mutants of Saccharomyces cerevisiae unresponsive to cell division control by polypeptide mating hormone. J. Cell Biol. 85: 811-822.

Herskowitz, I. 1989. A regulatory hierarchy for cell specialization in yeast. Nature 342: 749-757.

Irie, K., S. Nomoto, I. Miyajima, and K. Matsumoto. 1991. SGV1 encodes a CDC28/cdc2-related kinase required for a $G_{a}$ subunit-mediated adaptive response to pheromone in $S$. cerevisiae. Cell 65: 785-795.

Ito, H., Y. Fukuda, K. Murata, and A. Kimura. 1983. Transformation of intact yeast cells treated with alkali cations. $J$. Cell Biol. 153: 163-168.

Jenness, D.D., A.C. Burkholder, and L.H. Hartwell. 1983 Binding of $\alpha$-factor pheromone to yeast a cells: Chemical and genetic evidence for an $\alpha$-factor receptor. Cell 35: 521-529.

Johnston, M. and R.W. Davis. 1984. Sequences that regulate the divergent GAL1-GAL10 promoter in Saccharomyces cerevisiae. Mol. Cell. Biol. 4: 1440-1448.

Kamps, M.P. and B.M. Sefton. 1986. Neither arginine nor histidine can carry out the function of lysine-295 in the ATPbinding site of $60^{\mathrm{src}}$. Mol. Cell. Biol. 6: 751-757.

Kim, D., D. Lewis, L. Graziadei, E. Neer, D. Bar-Sagi, and D. Clapham. 1989. G-protein $\beta \gamma$-subunits activate the cardiac muscarinic $\mathrm{K}^{+}$-channel via phospholipase $\mathrm{A}_{2}$. Nature 337: $557-560$.

Kronstad, J.W., J.A. Holly, and V.L. MacKay. 1987. A yeast operator overlaps an upstream activation site. Cell 50:369377.

Kurjan, J. 1985. $\alpha$-Factor structural gene mutations in Saccharomyces cerevisiae mutants unresponsive to $\alpha$-factor production and mating. Mol. Cell. Biol. 5: 787-796.

Laemmli, U.K. 1970. Cleavage of structural proteins during the assembly of the head of bacteriophage T4. Nature 227: 680685.

Lipke, P.N., A. Taylor, and C.E. Ballou. 1976. Morphogenetic effects of $\alpha$-factor on Saccharomyces cerevisiae a cells. J. Bacteriol. 127: 610-618.

MacKay, V. and T.R. Manney. 1974a. Mutations affecting sexual conjugation and related processes in Saccharomyces cerevisiae. I. Isolation and phenotypic characterization of nonmating mutants. Genetics 76: 255-271.

- 1974b. Mutations affecting sexual conjugation and related processes in Saccharomyces cerevisiae. II. Genetic analysis of nonmating mutants. Genetics 76: 273-288.

McCaffrey, G., F.J. Clay, K. Kelsay, and G.F. Sprague Jr. 1987. Identification and regulation of a gene required for cell fusion during mating of the yeast Saccharomyces cerevisiae. Mol. Cell. Biol. 7: 2680-2690.

Miller, J. 1972. Experiments in molecular genetics. Cold Spring Harbor Laboratory, Cold Spring Harbor, New York.

Miyajima, I., M. Nakafuku, N. Nakayama, C. Brenner, K. Miyajima, K. Kaibuchi, Y. Arai, Y. Kaziro, and K. Matsumoto. 1987. GPA1, a haploid-specific essential gene, encodes a yeast homolog of mammalian G protein which may be involved in mating factor signal transduction. Cell 50: 10111019.

Nakayama, N., A. Miajima, and K. Arai. 1985. Nucleotide sequence of STE2 and STE3, cell-type specific sterile genes from Saccharomyces cerevisiae. EMBO /. 4: 2643-2648.

- 1987. Common signal transduction system shared by STE2 and STE3 in haploid cells of Saccharomyces cerevisiae: Autocrine cell cycle arrest results from forced expression of STE2. EMBO I. 6: 249-254.

Nomoto, S., N. Nakayama, K. Arai, and K. Matsumoto. 1990.
Regulation of the yeast pheromone response pathway by G protein subunits. EMBO I. 9: 691-696.

Reneke, J.E., K.J. Blumer, and J. Thorner. 1988. The carboxyterminal segment of the yeast $\alpha$-factor receptor is a regulatory domain. Cell 55: 221-234.

Rhodes, N., L. Connell, and B. Errede. 1990. STE11 is a protein kinase required for cell-type-specific transcription and signal transduction in yeast. Genes \& Dev. 4: 1862-1874.

Rothstein, R.J. 1983. One-step gene disruption in yeast. Methods Enzymol. 101: 202-211.

Saiki, R., D. Gelfand, S. Stoffel, S. Scharf, R. Higuchi, G. Horn, K. Mullis, and H. Erlich. 1988. Primer-directed enzymatic amplification of DNA with a thermostable DNA polymerase. Science 239: 487-491.

Sanger, F., S. Nicklen, and A.R. Coulson. 1977. DNA sequencing with chain-terminating inhibitors. Proc. Natl. Acad. Sci. 74: 5463-5467.

Schena, M., L.P. Freedman, and K.R. Yamamoto. 1989. Mutations in the glucocorticoid receptor zinc finger that distinguish interdigitated DNA binding and transcriptional enhancement activities. Genes \& Dev. 3: 1590-1601.

Sherman, F., G.R. Fink, and J.B. Hicks. 1986. Methods in yeast genetics. Cold Spring Harbor Laboratory, Cold Spring Harbor, New York.

Snyder, M.A., J.M. Bishop, J.P. McGrath, and A. Levinson. 1985.

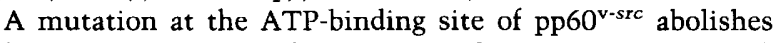
kinase activity, transformation, and tumorigenicity. Mol. Cell. Biol. 5: 1772-1779.

Song, O.-K., J.W. Dolan, Y.-I.O. Yuan, and S. Fields. 1991. Pheromone-dependent phosphorylation of the yeast STE12 protein correlates with transcriptional activation. Genes \& Dev. 5: 741-750.

Southern, E. 1975. Detection of specific sequences among DNA fragments separated by gel electrophoresis. I. Mol. Biol. 98: 503-517.

Sprague, G.F. Jr. and I. Herskowitz. 1981. Control of yeast cell type by the mating type locus. I. Identification and control of expression of the a-specific gene BARl. I. Mol. Biol. 153: 305-321.

Stryer, L. and H.R. Bourne. 1986. G-proteins: A family of signal transducers. Annu. Rev. Cell Biol. 2: 39l-419.

Teague, M.A., D.T. Chaleff, and B. Errede. 1986. Nucleotide sequence of the yeast regulatory gene $S T E 7$ predicts a protein homologous to protein kinases. Proc. Natl. Acad. Sci. 83: $7371-7375$.

Towbin, H., T. Staehelin, and J. Gordon. 1979. Electrophoretic transfer of proteins from polyacrylamide gels to nitrocellulose sheets: Procedure and some applications. Proc. Natl. Acad. Sci. 76: 4350-4354.

Van Arsdell, S.W. and J. Thorner. 1987. Hormonal regulation of gene expression in yeast. In Transcriptional control mechanisms (ed. D. Granner, M.G. Rosenfeld, and S. Chang), pp. 325-332. Alan R. Liss, New York.

Whiteway, M., L. Hougan, D. Dignard, D.Y. Thomas, L. Bell, G.C. Saari, F.J. Grant, P. O'Hara, and V.L. MacKay. 1989. The STE4 and STE18 genes of yeast encode potential $\beta$ and $\gamma$ subunits of the mating factor receptor-coupled G protein. Cell 56: 467-477.

Whiteway, M., L. Hougan, and D.Y. Thomas. 1990. Overexpression of the STE4 gene leads to mating reponse in haploid Saccharomyces cerevisiae. Mol. Cell. Biol. 10: 217-222.

Wilkinson, L.E. and J.R. Pringle. 1974. Transient G1 arrest of Saccharomyces cerevisiae of mating type $\alpha$ by a-factor produced by cells of mating type a. Exp. Cell Res. 58: 11071119. 


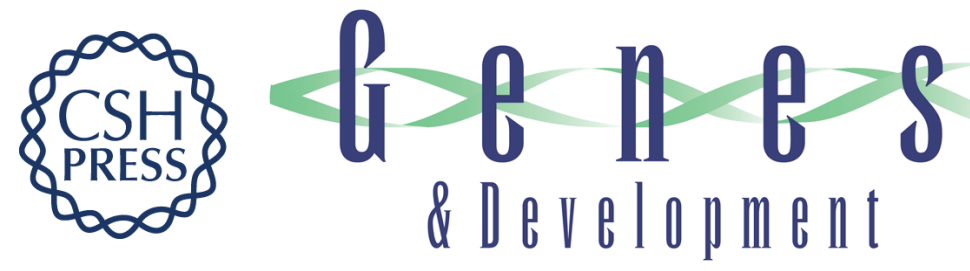

\section{Order of action of components in the yeast pheromone response pathway revealed with a dominant allele of the STE11 kinase and the multiple phosphorylation of the STE7 kinase.}

B R Cairns, S W Ramer and R D Kornberg

Genes Dev. 1992, 6:

Access the most recent version at doi:10.1101/gad.6.7.1305

References This article cites 64 articles, 31 of which can be accessed free at: http://genesdev.cshlp.org/content/6/7/1305.full.html\#ref-list-1

License

Email Alerting Receive free email alerts when new articles cite this article - sign up in the box at the top Service right corner of the article or click here.

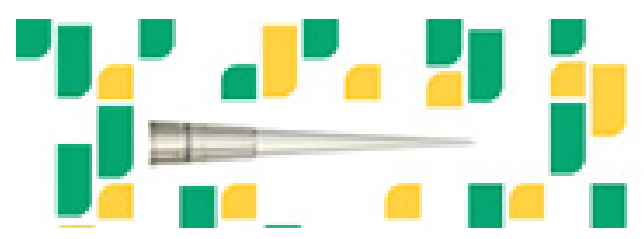

Focused on your science. 